more sections). The photographs are preserved in negative form on acetate safety film, which when tightly rolled is far more resistant to fire than any paper record. Working with quarto papers (10 in. $\times$ 8 in.), 1600 facsimiles can be obtained on $100 \mathrm{ft}$. of film. This micro-record occupies only one twentieth of the volume of the original. Full-size prints can be made from it at any time, or it can be read in a special projector, or thrown on a wall-screen for lectures. Preliminary arrangements are in hand for making micro-film records at the cost of one halfpenny per quarto document, possibly less if a sufficient volume of material is handled. Further information may be obtained from the Hon. Secretary, Research Co-ordination Committee, 35 Gordon Square, London, W.C.2.

\section{Old Science and Medicine}

E. P. Goldschmint AND Co., Ltd., of 45 Old Bond Street, have recently issued three catalogues entitled respectively "Science and Medicine", "English Science and Medicine" and "Old Medical Books". The first catalogue contains entries of a complete set in thirteen volumes of Johann Peter Frank's "Complete System of Medical Polity", the first edition of De Kempelen's works on the talking machine, the first German edition of Kepler's "Steriometria" and numerous original papers by Pasteur, Scheel and others. In the catalogue on "English Science and Medicine" we note the rare third edition of Harvey's "De Motu Cordis", Gilbert's "De Magnete", several works by Robert Boyle, including that on "The Mechanical Origine of Production of divers particular Qualities . . . of Magnetical Qualities", the first work on electricity in English, the first edition of Sir Robert Dudley's "Arcano del Mare", one of the foremost English works on navigation and several modern works by Huxley, Galton, Rutherford, Banting and Best, among others. Among the most notable works in the catalogue of "Old Medical Books" are the first edition of John Vigo's treatise on surgery in black letter (1543), the first illustrated edition of Dioscorides (1543), Sir Theodore Turquet de Mayerne's work on arthritis (1676), and the first editions of Laennec's book on auscultation (1819) and Semmelweis's on puerperal fever (1861).

\section{Eclipse of the Sun on April I9}

AN annular eclipse of the sun, partly visible as a partial eclipse from the British Isles, occurs on April 19 next. The annular phase is visible in Alaska and the Arctic Ocean. At Greenwich, the eclipse begins at $17^{\mathrm{h}} 29^{\mathrm{m}}$, the greatest phase $(0 \cdot 36)$ being reached at $18^{\mathrm{h}} 18^{\mathrm{m}}$; sunset is at $19^{\mathrm{h}} 2^{\mathrm{m}}$, just before the eclipse ends. The position angle of first contact is $298^{\circ}$ from the north point of the sun's image or $258^{\circ}$ from the vertex. At Edinburgh the corresponding times are : beginning $17^{\mathrm{h}} 17^{\mathrm{m}}$; greatest phase $(0 \cdot 44)$ at $18^{\mathrm{h}} 12^{\mathrm{m}}$; ending at $19^{\mathrm{h}} 3^{\mathrm{m}}$. The above times are in Universal Time; add $1 \mathrm{~h}$. to convert to Summer Time.

\section{The Night Sky in April}

THE moon is full on April 4 at $4 \cdot 3^{\mathrm{h}}$ and new on April 19 at $16 \cdot 6^{\mathrm{h}}$. The altitude of the full moon at transit at Greenwich on April $5^{\mathrm{d}} 0^{\mathrm{h}} 43^{\mathrm{m}}$ is $27 \frac{1}{2}^{\circ}$. Lunar conjunctions with the planets occur as follows : on April 10 with Mars; on April 16 with Venus; on April 17 with Jupiter; and on April 18 with Mercury. On April 22, Venus is in conjunction with Jupiter, the geocentric separation of the planets being only $0 \cdot 4^{\circ}$. The two planets rise, however, less than one hour before the sun. Mercury is at inferior conjunction with the sun on April 3 and is therefore not visible. Saturn is in conjunction on April 11 and likewise rises and sets with the sun. Mars still remains a morning star, rising about $1 \frac{1}{2}$ h in midApril. The only bright stars occulted during the month are $\psi$ Ophiuchi (mag. 4.6) on April 8 at $2^{\text {h }} 2 \cdot 9^{\mathrm{m}}$ (reappearance) as seen from Greenwich, and 26 Geminorum (mag. $5 \cdot 1$ ) on April 24 at $22^{\mathrm{h}} 12 \cdot 1^{\mathrm{m}}$ (disappearance). The Lyrid meteors, the radiant of which is near 104 Herculis, are due at their maximum between April 19 and 22, but in some years they are nearly absent. All the above times are given in universal time (U.T.). Summer Time begins on April 16.

\section{Announcements}

Mr. J. E. Montgomrey has been appointed secretary of the Institution of Mechanical Engineers in succession to Brigadier-General Magnus Mowat, who has retired on account of ill-health. Mr. Montgomrey has been assistant secretary of the Institution since 1920 .

THE Rockefeller Foundation has announced that during the next seven years it will grant a sum not exceeding $£ 12,000$ to the Imperial College of Science and Technology, South Kensington, for research on vitamins, sterols and related compounds under the direction of Prof. I. M. Heilbron.

AN Institute for Research in Aeronautical Medicine has recently been founded at Mount Fuji, Japan.

IN 1938 the number of deaths in France was 40,000 higher than the number of births, while in Italy the births exceeded the deaths by 424,000 and in Germany by 500,000 .

THE University of Peiping, which was closed at an earlier stage of the Sino-Japanese War, has recently been reopened under the direction of Prof. Hisomu Nagat, formerly of the University of Formosa.

We have received a part of the Collection Scientifique issued by the Institut Internationale de Coopération Intellectuelle (1938), entitled "Les déterminations physico-chimiques des poids moléculaires et atomiques des gaz", price 45 francs. The volume contains papers by Moles, Whytlaw-Gray, Cawood, Keesom and others, a long discussion and addenda. 